\title{
Introduction: Looking Back and Looking Forward
}

\author{
The Editors
}

This issue of ECA takes as its theme the importance of looking back in order the better to look forward. We can apply this in the first instance to our role as editors: this is the final edition of the journal to be published by Liverpool University Press. As from ECA 5.1 in July 2012, ECA will be published by Oxford and New York-based Berghahn, one of the leading independent academic publishers, with specialisations in cultural studies and visual media.

As our collaboration with Liverpool University Press ends, we can look back over the four years that we have worked with our colleagues at the press (especially Robin Bloxsidge, Patrick Brereton, Anthony Cond, Clare Hooper and Helen Tookey), and express our gratitude for their support in enabling us to found the first academic journal dedicated to the scholarly study of European comic art. During that period, comics scholarship has continued to expand, with an increase in the number of PhD theses devoted to the subject, conferences held, and delegates attending those conferences. As clear evidence of the liveliness of the comics research culture, we can cite the ever greater number of high-quality submissions that we are receiving. We would take this opportunity to thank not only all our contributors but also the many scholars who have acted as peer reviewers for us: their critical reading is a key part of the process of producing the journal. We also, of course, very warmly thank our readers and subscribers, both individual and institutional. We would greatly appreciate it if all our readers could persuade their libraries to subscribe to the journal. The more institutional subscriptions we can acquire, the more established we will be, the more recognised the field of comics scholarship as a whole will become, and the better we will be able to serve the community of comics scholars, whose achievement over the last few years (whether or not they have been closely involved with $E C A$ ) has been remarkable. There is much to build on as we look forward to our new partnership with Berghahn.

Our first article, by the pioneering comics theoretician Pierre FresnaultDeruelle, looks at references back and forth as a structuring element of two 


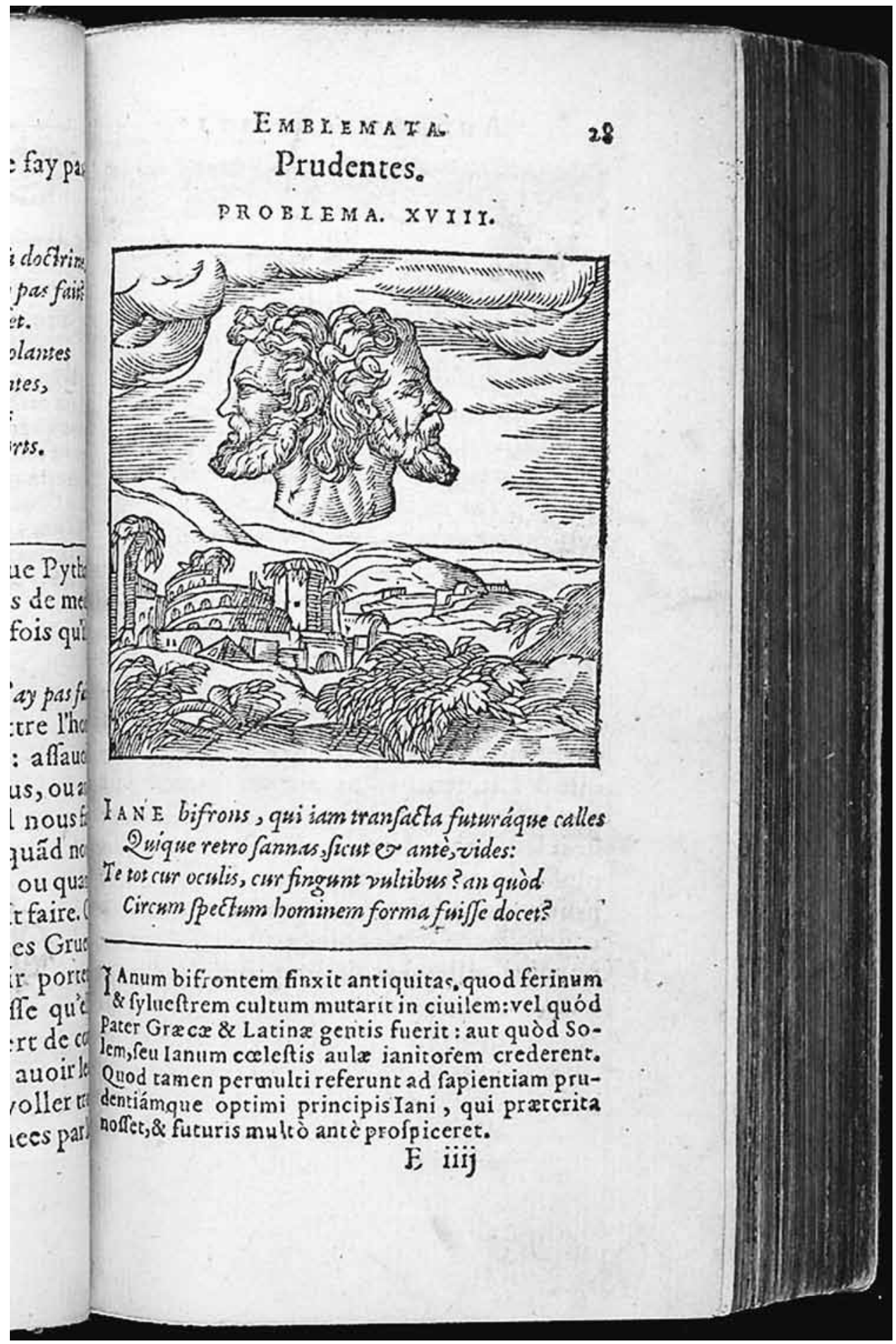

Andrea Alciato, 'Prudentes' ['The Wise'], Emblemata (Paris: Jean Richer, 1584), fo. E4 ${ }^{\mathrm{r}}$. Glasgow University Library SM 283. 
Tintin albums, Les 7 Boules de cristal and Le Temple du Soleil. ${ }^{1}$ Thierry Groensteen's well-known notion of tressage ['braiding'] is mobilised here as an active principle of reading, as Fresnault-Deruelle argues that the dramatic impact of the work is heightened by the systematic foreshadowing of subsequent events and echoing of previous ones. The mysteries that unfold in the Temple of the Sun are all the more disturbing for reprising, in solemn mode, earlier comic attempts at cheap conjuring tricks, a debased Western version of the magic invoked by the ancient ceremonial of the Incas.

Richard Scully delves back into comics history with an exploration of the cartoon industry generated by opposition to the tyrannical regime of Louis Napoleon Bonaparte, but brings a new critical perspective to this material. These graphic works are often studied as an early example of the power of satirical images to affect the shaping of national identities, which may then be further inflected by ripostes in the form of censorship and repression. Scully is more concerned, though, to consider caricatures of the French Emperor as a transnational phenomenon: French cartoonists were able to escape the censors by publishing abroad, émigré communities were provided with a rallying point, and the satirical press in Britain, Germany and Russia, while demonising the figure of Louis Napoleon in relation to the specific threat that he posed to their own national interests, frequently drew on common, including classical, imagery to do so. Scully's analysis of the cartoon Emperor as a European creation points to the potential for further research into a pan-European comic art, a complex interplay of influences rather than a mere aggregation of different national traditions.

Annabelle Cone also returns to a figure from the early history of comic art, Bécassine, and, like Scully, brings a new perspective. She rereads Bécassine chez les Turcs through a postcolonial lens, ${ }^{2}$ and contends that this album disturbs colonial stereotypes rather than confirming them, thereby running counter to the compliant conservatism that critics have tended to see in the series. Cone argues that Bécassine's own position as a maid and a member of a despised regional minority group means that she is already well placed to make the hierarchical social order visible. Once the upheavals of war have enabled her to escape her domestic environment she is able to mix with fellow outsiders, most notably the young Arab whose treatment by the French may incite the album's young readers to question France's claims to be a civilising influence on the world stage. Cone's work suggests that there may be further ideological contradictions to be uncovered by close scrutiny of the adventures of Bécassine, set in a world undergoing massive historical change, and giving rise to tensions not entirely contained by the reassuring authority of the narrative.

1 Hergé, Les 7 Boules de cristal ['The Seven Crystal Balls'] (Tournai: Casterman, 1948); Hergé, Le Temple du Soleil ['Prisoners of the Sun'] (Tournai: Casterman, 1949).

2 Caumery and Pinchon, Bécassine chez les Turcs (Paris: Gautier-Languereau, 1919). 
Bart Beaty pursues our theme of backward and forward vision. He revisits the oft-rehearsed debate over the potential of a single image to constitute a comic, but refocuses it by insisting on the importance of the distinctive graphic line as the basis of the appeal of a particular series to its readers, an appeal that persists even as fragments of a comic are sampled and remixed in a new context. Moreover, he takes as a point of departure for his discussion the recent re-envisioning by Émile Bravo of another famous figure from comics history, namely Spirou, in an album that rewrites history and politics back into the more indeterminate original. ${ }^{3}$ In addition, the inclusion of the painter Magritte alongside both Spirou and Hergé (and a sketch of Tintin) in a single image produced by Bravo for a book about Brussels enables Beaty to draw out the implied parallel between the work of the Belgian surrealist, serial re-appropriator of canonical works, and Bravo's own project of critical homage. ${ }^{4}$ Above all, Beaty's article offers a demonstration of the productiveness of an approach centred on style.

Finally, we publish the first half of an interview by Mark McKinney with the great comics artist Baru, twice winner of the Best Album prize at Angoulême, and this year's president of the Festival after achieving the accolade of Grand Prix in 2010. In it, Baru discusses the cartoonists, writers, filmmakers and musicians who have influenced him, and offers his insights and reflections about the Angoulême festival. In response to McKinney's questions, he then moves on to issues that can be related to the theme of this edition of European Comic Art. He explains that if the Algerian War continually recurs in his work, this is because unresolved tensions from that period still have social and political effects in France. His comics offer the possibility of helping readers to work out a relationship to the past that otherwise lies beneath the surface, with resentments passed down through the generations. Baru also stresses his concern to acknowledge the importance of the working-class political culture within which he grew up, even if he is critical of the Stalinism that ultimately perverted and betrayed the aspirations of the militants like those depicted in many of his albums set in the 1950 os and 1960 s. $^{5}$ The loss of that political culture has resulted in a loss of class consciousness, he argues, and has allowed the right to set the agenda. Baru's work is a powerful argument in support of our theme: the necessity of looking back to the past in order to understand where we are now and where we are going.

We therefore offer you an issue of ECA that faces in two directions. Our contributors have turned their gaze onto the history of comic art, but in so doing they have brought fresh critical viewpoints, and have offered produc-

3 Émile Bravo, Spirou, le journal d'un ingénu ['Spirou, the Diary of a Naive Young Man'] (Brussels: Dupuis, 2008).

4 See http://www.champaka.be/les-estampes-316.

5 The interview is followed by a comprehensive bibliography of Baru's works, but see in particular the four-volume Les Années Spoutnik ['The Spoutnik Years'] (Tournai: Casterman, 1999-2003). 
tive and provocative rereadings, opening up the way to further research into figures whose cultural meanings continue to evolve. As the journal itself is entering a new phase, looking both back and forwards remains our goal. Like the image-mongers of the sixteenth century, we hope, now and in the future, to prove our wisdom by drawing upon knowledge of the past so as to enliven our understanding of the future. 